\title{
Evaluasi Mikrobiologi dan Sifat Mekanik Kateter Penghisap yang Dipakai Ulang: Perbandingan antara Dua Prosedur Pemrosesan
}

\author{
Elisa, ${ }^{1}$ S.H. Purwanto, ${ }^{1}$ A.T. Aman, ${ }^{2}$ Y. Pranoto, ${ }^{3}$ Kusmono ${ }^{4}$ \\ ${ }^{1}$ Unit Rawat Intensif, Jogja International Hospital, Jogjakarta, ${ }^{2}$ Departemen Mikrobiologi, Fakultas Kedokteran \\ Universitas, Gadjah Mada, ${ }^{3}$ Departemen Teknologi Pangan dan Hasil Pertanian, Fakultas Teknologi Pertanian, \\ ${ }^{4}$ Departemen Teknik Mesin dan Industri, Fakultas Teknik, Gadjah Mada Yogyakarta, Indonesia
}

\begin{abstract}
Latar belakang. Pemakaian ulang kateter penghisap telah biasa dilakukan di Indonesia, namun sejauh ini belum ada penelitian mengenai sterilitas dan keamanannya.

Tujuan. Mengevaluasi sterilitas, sifat mekanik, dan permukaan serta kualitas matriks kateter penghisap yang dipakai ulang setelah diproses dengan dua jenis prosedur pengolahan yang berbeda.

Metode. Kateter penghisap yang dipakai ulang setelah diproses dan disterilisasi menggunakan gas etilen oksida (EO), atau menggunakan sterilisasi pemanasan kering (kelompok B). Semua sampel dibersihkan dan didesinfeksi dengan prosedur yang hampir sama. Kateter penghisap baru dipakai sebagai standar. Mikroba yang tumbuh pada medium kultur diidentifikasi. Semua sampel menjalani uji tarik dan kompresi. Analisis mikrostruktur dilakukan dengan menggunakan mikroskop elektron (SEM) dan energi-dispersif spektroskopi sinar-X (EDX).

Hasil. Kultur positif bakteri komensal pada 6 di antara 15 sampel pada kelompok A, dan 6 dari 17 sampel pada kelompok B. Terdapat perbedaan yang bermakna dari sifat mekanik sampel penelitian $(p<0,05)$. Sampel dari kelompok A memiliki kekuatan yang paling rendah. Sampel dari kedua kelompok penelitian mengalami perubahan kelenturan dan keuletan dibanding standar. Analisis mikrostruktur menggunakan XPS dan EDX pada permukaan dalam ujung kateter penghisap yang dipakai ulang menunjukkan degradasi komponen matriks. Analisis SEM mendeteksi beberapa partikel tambahan dan rekahan. Analisis EDX pada partikel tambahan menunjukkan pengayaan sinyal $\mathrm{na}^{+}$dan $\mathrm{ca}^{++}$. Secara keseluruhan, didapatkan tanda kontaminasi serta kerusakan material.

Kesimpulan. Kedua metode pengolahan ulang kateter penghisap memberikan hasil sterilitas yang sebanding. Sampel yang dipakai ulang mengalami penurunan kekuatan, menjadi lebih lentur, dan tidak ulet. Ditemukan tanda kontaminasi, perubahan sifat permukaan dan kerusakan matriks dari kateter penghisap yang dipakai ulang. Sari Pediatri 2011;12(5):328-34.
\end{abstract}

Kata kunci: kateter penghisap, pemrosesan ulang, evaluasi

\footnotetext{
Alamat korespondensi:

Dr. Elisa, Sp.A. Unit Rawat Intensif, Jogja International Hospital, jl. Ring Road Utara 160, Condong Catur, Jogjakarta, Indonesia. Telp.: 0274-4463535, Fax.0274-411368, E-mail: cica@indosat.net.id
}

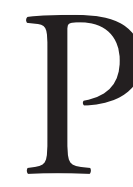

emakaian ulang peralatan medis sekali pakai dilaksanakan sejak akhir $1970 .{ }^{1}$ Sebelumnya, sebagian besar peralatan medis dianggap dapat dipakai ulang. Keputusan untuk memakai ulang 
sebagian dari peralatan medis sekali pakai meningkat sejalan dengan langkah-langkah penghematan biaya. Tindakan ini menyangkut berbagai kebijakan, etika, medis, hukum, isu ekonomi, dan menjadi bahan perdebatan kontroversial selama lebih dari dua dekade. Studi lebih jauh diperlukan untuk menentukan besarnya risiko dan manfaat pemakaian ulang peralatan medis sekali pakai tersebut. ${ }^{1}$ Di Indonesia, pengolahan kembali alat medis untuk dipakai ulang bisa menjadi alternatif untuk mengurangi biaya dan mengantisipasi ketersediaan 'perangkat impor'. Sejauh ini, belum ada standar dan evaluasi hasil pemrosesan ulang terhadap alat medis sekali pakai.

Pemrosesan ulang (pembersihan ulang, desinfeksi dan sterilisasi) terhadap alat-alat medis dengan lumen yang sempit, seperti kateter penghisap, merupakan hal yang sulit dikerjakan. ${ }^{2,3,4}$ Hal ini bahkan menjadi dilema besar apabila perangkat medis tersebut telah diberi label sebagai peralatan sekali pakai. Di beberapa negara, ada berbagai kebijakan yang menyangkut isu pemakaian ulang alat medis sekali pakai. ${ }^{4}$ Pemakaian ulang alat medis sekali pakai di Asia, Kanada, dan Amerika Selatan, terus dilakukan di tengah kontroversi tentang keamanan pemakaiannya. ${ }^{4}$ Pemakaian ulang alat medis sekali pakai telah dilakukan di Indonesia tanpa adanya bukti keamanannya.

Kateter penghisap digunakan untuk membersihkan saluran udara artifisial pada pasien sakit berat di ruang rawat intensif. Hal ini bertujuan agar saluran udara tidak tersumbat, bebas dari sekresi cairan yang dapat menyebabkan kolonisasi kuman. Tindakan penghisapan cairan sekresi ini bisa dilakukan beberapa kali dalam sehari sesuai kebutuhan pasien. Idealnya, setiap kali tindakan penghisapan harus menggunakan kateter penghisap yang baru untuk menjaga sterilitas. Namun hal tersebut memerlukan biaya tinggi, sehingga diupayakan untuk melakukan pemrosesan ulang kateter penghisap supaya bisa dipakai ulang guna menghemat biaya. Kateter penghisap terbuat dari bahan polivynil chlorida (PVC) yang jernih tembus pandang yang bermanfaat untuk mengamati warna dan kualitas cairan yang dihisap. ${ }^{5}$ Alat ini bebas lateks. Pemrosesan ulang kateter penghisap yang terbuat dari PVC dengan berbagai kualitas bahan matriks merupakan aspek penting karena polimer memiliki kestabilan yang lebih rendah secara termal maupun kimiawi dibandingkan dengan material lainnya. ${ }^{6}$ Tujuan penelitian untuk mengevaluasi sterilitas, sifat mekanik, dan permukaan serta kualitas matriks kateter penghisap yang dipakai ulang setelah diproses dengan dua jenis prosedur pengolahan yang berbeda.

\section{Metode}

Sampel kateter penghisap berasal dari dari Unit Rawat Intensif Anak RSCM Jakarta. Pengambilan sampel dalam kurun waktu Juni hingga Desember 2006 dilakukan dalam dua kesempatan yang berbeda. Kriteria pengambilan sampel adalah kateter penghisap yang dipakai dan telah diproses ulang dua kali tanpa adanya kerusakan yang terlihat. Semua sampel dibuat oleh produsen yang sama. Pemrosesan ulang dilakukan di dua departemen yang berbeda di rumah sakit yang sama. Prosedur pengolahan yang dilakukan di sub Unit Neonatal disebut sebagai Prosedur A, sedangkan prosedur pengolahan yang dilakukan di sub Unit Rawat Intensif Anak disebut sebagai prosedur B. Prosedur A terdiri dari pembersihan alat secara manual dengan menggunakan cairan deterjen konsentrasi normal. Kateter direndam di dalam larutan sodium hipoklorit $(\mathrm{NaOCl}) 2500$ ppm dalam waktu 2 jam, dikeringkan dengan jalan digantung atau ditiup dengan udara kering, dimasukkan ke dalam paket sterilisasi, kemudian disterilkan dengan gas etilen oksida (Anprolene AN74i). Pada prosedur B kateter direndam dengan savlon dalam waktu 48 jam, dibersihkan secara manual dengan menggunakan cairan deterjen biasa, kemudian direndam dalam larutan sodium hipoklorit 5000 ppm dalam waktu 2 jam, dikeringkan dengan jalan digantung atau ditiup dengan udara kering, dikemas dengan kain bersih, kemudian disterilisasi menggunakan alat sterilisasi panas kering (Memmert Ule 600 SS oven GmbH + co KG (Jerman).

Pemeriksaan mikrobiologi dilakukan di Departemen Mikrobiologi, Fakultas Kedokteran Universitas Gadjah Mada Yogyakarta, Indonesia. Didapatkan 12 sampel kateter penghisap dari pemrosesan dengan menggunakan prosedur A dan 17 buah dari prosedur B. Seluruh sampel dibilas dengan normal saline steril pada permukaan luar maupun dalam. Larutan hasil pembilasan dibiak dalam agar darah, agar Mac Conkey,agar Saboroud, dan medium agar thioglycolate (masing-masing 0,1 $\mathrm{ml}$ ). Semua dilaksanakan dalam kondisi aseptik. Studi mikrobiologi tidak dilakukan terhadap kateter 
penghisap yang baru (contoh standar), karena alat tersebut dianggap steril. Kolonisasi mikroba dideteksi dan diidentifikasi pada sampel kultur pada hari ketujuh masa inkubasi di bawah mikroskop dan juga menggunakan reaksi biokimia. Jumlah koloni yang tumbuh dinyatakan sebagai colony forming unit per milimeter $(\mathrm{CFU} / \mathrm{ml})$. Analisis statistik dilakukan dengan menggunakan Fischer exact test untuk sampel kecil. Signifikansi statistik diterima pada $\mathrm{p}<0,05$.

Evaluasi sifat mekanik dilakukan dengan menggunakan mesin Universal Testing (Zwick, DO-FB0.5TS) di Departemen Teknologi Pangan dan Hasil Pertanian, Fakultas Teknologi Pertanian, Universitas Gadjah Mada Yogyakarta, Indonesia. Evaluasi sifat mekanik yang diukur meliputi uji tarik dan kompresi, bertujuan untuk menentukan sifat mekanik (kekuatan dan daktilitas) kateter penghisap yang dipakai ulang dalam perbandingan dengan sampel standar. Didapatkan empat sampel dari setiap kelompok penelitian. Kurva deformasi beban dicatat dari $\mathrm{F}$ maks dan regangan di F maks. Pada uji tarik, F maks didefinisikan sebagai beban maksimum yang diperlukan oleh sampel hingga mengalami peregangan maksimal. Regangan di $\mathrm{F}$ maks adalah persentase pemanjangan pada saat sampel mengalami peregangan maksimal. Sedangkan pada uji tekan F maks adalah beban maksimum yang diperlukan untuk lumen sampel untuk mengempis sepenuhnya, pengempisan di $\mathrm{F}$ maks adalah persentase pengurangan diameter sampel pada saat lumen mengempis sepenuhnya. Distribusi rerata dan simpang baku dari semua parameter dianalisis secara deskriptif dengan menggunakan Kolmogorov-Smirnov Z. Analisis perbedaan terhadap semua nilai dibandingkan dengan
Anova. Signifikansi statistik diterima pada $\mathrm{p}<0,05$.

Analisis elektron mikroskopik (SEM) dan Energidispersif Spektroskopi sinar-X (EDX) dilakukan dengan menggunakan mesin Analytical Scanning Electron Microscope (JEOL, JSM-636OLA) di Institut Geologi Kelautan, Bandung, Indonesia. Foto SEM dibuat dengan perbesaran 1000x. Sampel diambil dari permukaan dalam bagian distal lumen kateter penghisap yang baru (standar) dan dari sampel kateter penghisap kelompok A dan B. Dilakukan analisis terhadap perubahan material matriks dan adanya perubahan atau peningkatan jumlah partikel pada permukaan sampel. Mesin EDX digunakan bersamaan dengan SEM untuk mengidentifikasi komposisi dan menentukan karakter kimia dari spesimen sampel. Perubahan unsur-unsur kimia dan senyawa tertentu (karbon, oksigen, nitrogen, silikon, natrium, kalsium, zink, dan klorin) pada sampel menunjukkan adanya degradasi material matriks atau residu cairan desinfektan.

\section{Hasil}

Ditemukan kultur positif Bacillus sp pada empat sampel (masing-masing $10 \mathrm{CFU} / \mathrm{ml}$ ), dan kultur positif Staphylococcus sp pada dua sampel (masing-masing 5 CFU/ml) dari 15 sampel pada kelompok A. Kultur positif Bacillus sp juga ditemukan pada enam sampel (masing-masing $10 \mathrm{CFU} / \mathrm{ml}$ ) dari 17 sampel pada kelompok B. Tidak terdapat perbedaan yang bermakna secara statistik dari hasil tersebut.

Uji tarik terhadap sampel dari kelompok penelitian mendapatkan hasil nilai $F$ maks yang berbeda

Tabel 1. Perbedaan rerata dan pemanjangan/pengempisan F Maks uji tarik dan uji kompresi

\begin{tabular}{|c|c|c|c|c|c|c|c|}
\hline Uji tarik dan uji kompresi & $\begin{array}{c}\text { Standar } \\
\mathrm{n}=4\end{array}$ & $\begin{array}{c}\text { Kelompok A } \\
\mathrm{n}=4\end{array}$ & $\begin{array}{c}\text { Kelompok B } \\
\mathrm{n}=4\end{array}$ & $\begin{array}{c}\text { Jumlah } \\
\mathrm{n}=12\end{array}$ & $\mathrm{p}$ & $\begin{array}{c}\mathrm{p} \\
\text { Standar } \\
- \text { Kelompok } \\
\text { A } \\
\end{array}$ & $\begin{array}{c}\mathrm{p} \\
\text { Standar } \\
- \text { Kelompok } \\
\text { B } \\
\end{array}$ \\
\hline \multicolumn{8}{|l|}{ Uji tarik, n (SB) } \\
\hline F Maks & $35,5(2,5)$ & $25,8(5,3)$ & $36,1(3,2)$ & $32,5(6,1)$ & $0,007^{*}$ & $0,015^{*}$ & 0,974 \\
\hline Pemanjangan di F Maks & $181,0(9,0)$ & $212,8(72,5)$ & $177,2(28,35)$ & $190,4(44,2)$ & 0,502 & 0,600 & 0,992 \\
\hline \multicolumn{8}{|l|}{ Uji kompresi, n (SB) } \\
\hline F Maks & $26,6(3,8)$ & $7,2(0,3)$ & $20,1(1,0)$ & $18,0(8,7)$ & $<0,001^{*}$ & $<0,001^{*}$ & $0,007^{*}$ \\
\hline Pengempisan di F Maks & $1,2(0,1)$ & $1,1(0,0)$ & $1,1(0,1)$ & $1,2(0,1)$ & 0,096 & 0,083 & 0,372 \\
\hline
\end{tabular}

${ }^{*} \mathrm{P}<0.05$ (signifikan) 
bermakna (Tabel 1). Sampel dari kelompok A memiliki nilai $\mathrm{F}$ maks yang paling rendah di antara semua sampel penelitian (Gambar 1). Namun demikian, tidak didapatkan perbedaan yang bermakna dari nilai regangan di $\mathrm{F}$ maks. Hasil uji kompresi terhadap sampel penelitian juga memperlihatkan hasil yang berbeda bermakna dari nilai F maks. Baik sampel dari kelompok A maupun B masing-masing memiliki nilai F maks yang lebih rendah dibanding standar. Tidak didapatkan perbedaan yang bermakna dari nilai-nilai pengempisan di F maks antar kelompok penelitian.

Analisis SEM memperlihatkan permukaan dalam kateter penghisap yang baru tampak bersih dan rata, material matriks tampak homogen (Gambar 2). Sedangkan pada permukaan kateter penghisap baik dari kelompok A maupun B terlihat partikel-partikel tambahan yang cukup besar tersebar, dan material matriks tampak sudah tidak homogen lagi (Gambar

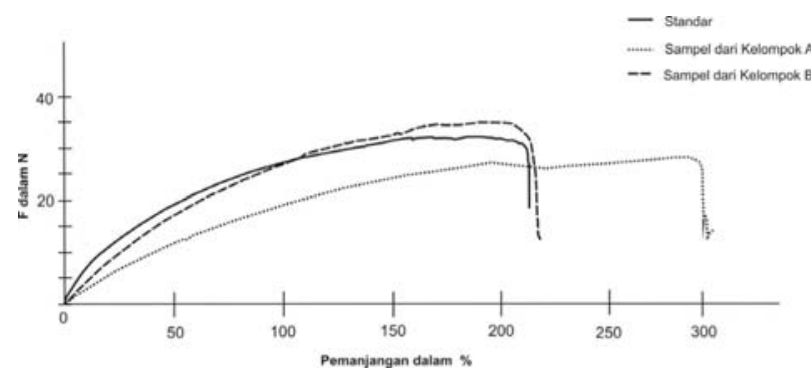

Gambar 1. Kurva deformasi beban pada uji tarik
3 dan 4). Terlihat adanya perubahan warna pada beberapa bagian permukaan kateter penghisap yang telah dipakai ulang.

Analisis dengan mesin EDX menunjukkan bahwa material matriks dari kateter penghisap yang baru memancarkan sinyal oksigen $(\mathrm{O})$, karbon (C), dan klor (Cl) yang merupakan matriks dasar PVC. Sedangkan analisis terhadap kateter penghisap yang telah dipakai ulang mendeteksi adanya perubahan pancaran sinyal, yaitu peluruhan sinyal $\mathrm{O}$ dan sinyal $\mathrm{C}$, peningkatan sinyal $\mathrm{Cl}$, serta pengayaan sinyal silikon $(\mathrm{Si})$ dan nitrogen (N) (Tabel 2). Analisis EDX terhadap partikel

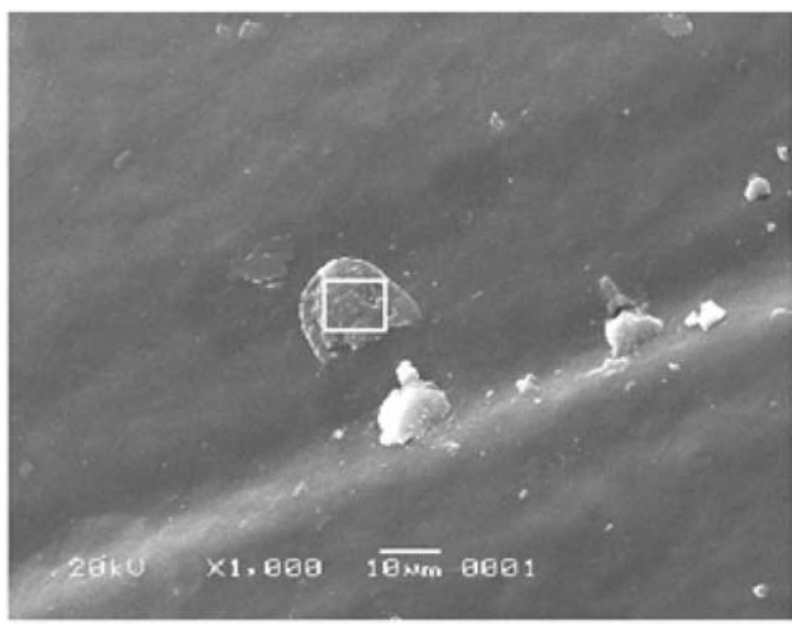

Gambar 5. Analisis EDX terhadap partikel tambahan mendeteksi adanya pengayaan sinyal $\mathrm{Na}, \mathrm{Ca}, \mathrm{Al}$, dan $\mathrm{Zn}$.

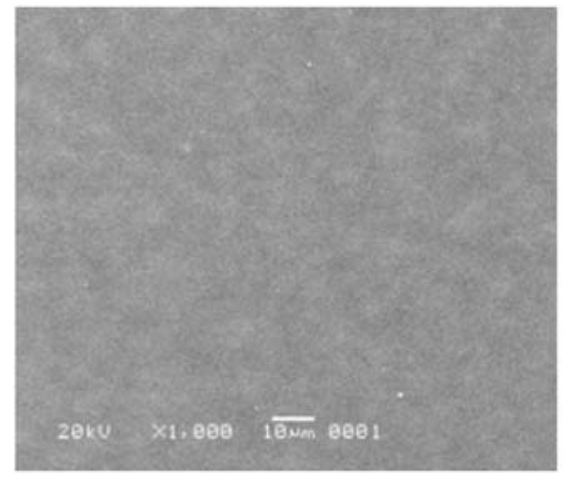

Gambar 2

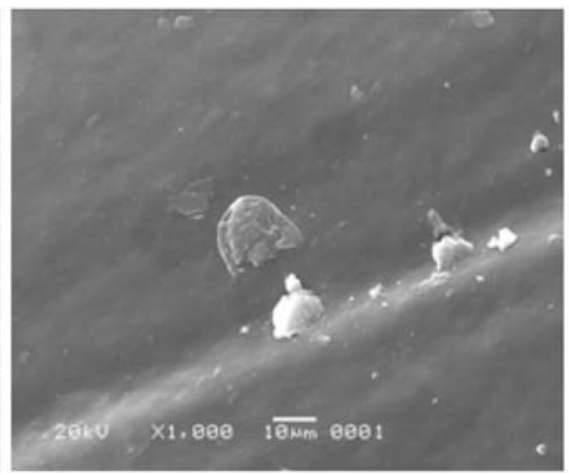

Gambar 3

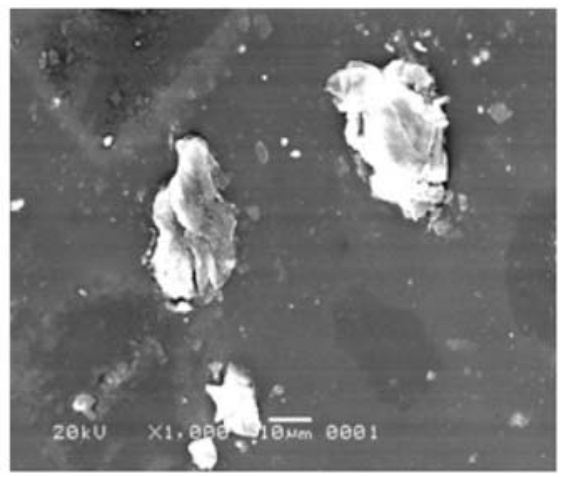

Gambar 4

Keterangan gambar:

Gambar 2. Analisis SEM (perbesaran 1000x) dari sampel standar. Permukaan tampak bersih dan rata serta homogen.

Gambar 3. Analisis SEM (perbesaran 1000x) dari sampel kelompok A. Tampak partikel-partikel tambahan pada permukaan sampel. Gambar 4. Analisis SEM (perbesaran 1000x) dari sampel kelompok B. Tampak partikel-partikel tambahan pada permukaan sampel, perubahan warna, dan material matriks yang sudah tidak homogen. 
Elisa dkk: Evaluasi mikrobiologi dan sifat mekanik kateter penghisap pakai ulang pada dua prosedur pemrosesan

Tabel 2. Hasil analisis EDX

\begin{tabular}{lccccc}
\hline \multirow{2}{*}{ Kelompok } & & \multicolumn{3}{c}{ Unsur kimia (konsentrasi \%) } & \multirow{2}{*}{ N\% } \\
\cline { 3 - 4 } & $\mathrm{O} \%$ & $\mathrm{C} \%$ & $\mathrm{Cl} \%$ & $\mathrm{Si} \%$ & \\
Baru & 5,17 & 73,61 & 21,22 & & \\
Kelompok A & & 52,27 & 47,73 & & \\
Kelompok B & & 42,04 & 32,26 & 0,06 & 25,64 \\
\hline
\end{tabular}

tambahan menunjukkan adanya pengayaan sinyal natrium $(\mathrm{Na})$, alumunium $(\mathrm{Al})$, kalsium $(\mathrm{Ca})$, dan zink (Zn) (Gambar 5).

\section{Pembahasan}

Perangkat medis yang diberi label sekali pakai kadangkala diproses dan dipakai ulang untuk pasien lain. Pemrosesan ulang seharusnya meliputi pembersihan dan sterilisasi ulang terhadap peralatan medis serta memastikan bahwa peralatan tersebut berfungsi dengan baik sesuai aslinya. Peralatan medis yang diproses ulang dapat dibagi menjadi tiga kelompok. ${ }^{7} 1$. Peralatan medis kritis dimaksudkan sebagai alat medis yang selama penggunaannya berhubungan dengan jaringan atau rongga tubuh yang steril. 2. Peralatan medis semikritis dimaksudkan sebagai alat medis yang selama penggunaannya berhubungan dengan selaput lendir yang utuh dan tidak menembus daerah steril tubuh. 3. Peralatan medis non kritis dimaksudkan sebagai alat medis yang selama penggunaanya bersifat topikal dan tidak menembus kulit utuh. Menurut klasifikasi tersebut, maka kateter penghisap termasuk dalam kelompok peralatan medis kritis. Praktek pemrosesan dan pemakaian ulang peralatan medis menimbulkan masalah kesehatan di masyarakat, terutama berkaitan dengan risiko infeksi dan malfungsi alat. ${ }^{8}$

Data mikrobiologi dari penelitian kami menunjukkan baik prosedur pembersihan dan sterilisasi memberikan hasil yang sama. Tidak didapatkan kuman Pseudomonas aeruginosa pada semua sampel. Pseudomonas aeruginosa merupakan salah satu jenis bakteri yang paling banyak menyebabkan infeksi nosokomial (30\%). ${ }^{9}$ Data dari studi yang dilakukan oleh Merrit dkk (1999) ${ }^{9}$ menunjukkan bahwa deterjen dengan surfaktan memiliki kemampuan pembersihan tidak lebih dari air, sedangkan larutan $\mathrm{NaOCl}$ justru sangat efektif menghilangkan bakteri. Pada penelitian kami, desinfektan yang digunakan memiliki potensi virisidal yang tinggi, sehingga bisa diasumsikan bahwa kateter penghisap yang diuji juga bebas virus. ${ }^{10,11,12}$ Merrit $\mathrm{dkk}^{9}$ juga membuktikan bahwa baik deterjen maupun larutan $\mathrm{NaOCl}$ sangat efektif dalam menghilangkan darah yang sering merupakan kontaminan dari perangkat medis yang dibersihkan untuk digunakan kembali.

Sterilisasi dengan menggunakan gas EO sebenarnya telah banyak dipakai dengan berbagai model intrumennya, namun senyawa itu memiliki efek toksik. Oleh karena itu, perlu dilakukan detoksifikasi sebelum alat medis dipakai. ${ }^{13} \mathrm{Di}$ institusi tempat penelitian dilakukan, gas EO relatif mahal dan harus diimpor, sehingga digunakan sterilisasi panas kering sebagai metode alternatif sterilisasi. Metode sterilisasi tersebut dianggap lebih murah dan sederhana. Kerugian penggunaan metode panas kering adalah suhu pemanasan yang melebihi suhu maksimum yang dapat diterima oleh material PVC sebelum mencair. ${ }^{6,12}$ Selain pembersihan dan desinfeksi yang efektif yang meliputi penghilangan residu serta partikel dari permukaan alat medis, efek buruknya terhadap permukaan dan struktur matriks harus juga dipertimbangkan.

Uji mekanik yang terdiri dari uji tarik dan kompresi dapat digunakan untuk mengetahui sifat dasar material. ${ }^{14} \mathrm{Uji}$ mekanik digunakan untuk menentukan kekuatan, daktilitas, dan keuletan kateter penghisap yang diproses ulang dibandingkan dengan alat yang baru. Data baik dari uji tarik maupun kompresi menunjukkan kateter penghisap yang diproses ulang mengalami penurunan kekuatan. Gambar kurva deformasi beban juga memberikan kesan bahwa kateter penghisap yang dipakai ulang menjadi lebih lentur (daktil) dan tidak ulet lagi. Keadaan ini menunjukkan bahwa pada saat dipakai untuk menghisap, lumen alat tersebut menjadi lebih mudah kolaps.

Sejalan dengan perubahan sifat mekaniknya, maka dari analisis SEM didapatkan gambaran perubahan sifat permukaan sampel yang diproses ulang yang menjadi tidak rata dan tidak homogen seperti sampel asli. 
Gambaran tersebut penting untuk ditinjau mengingat permukaan yang kasar akan mempermudah perlekatan bakteri. ${ }^{15,16}$ Terdeteksi juga adanya partikel tambahan pada permukaan sampel yang dipakai ulang. Peluruhan sinyal $\mathrm{O}$ dan $\mathrm{C}$ pada sampel yang dipakai ulang merupakan indikasi degradasi komponen dasar matriks, sedangkan peningkatan sinyal $\mathrm{Cl}$, serta pengayaan sinyal Si dan $\mathrm{N}$ membuktikan adanya residu desinfektan (Cl) dan kontaminasi. Analisis EDX pada partikel tambahan membuktikan bahwa partikel tersebut adalah kontaminan karena kandungan unsur-unsurnya berbeda dari matriks dasar material sampel.

Penelitian kami hanya menggunakan satu merek kateter penghisap yang paling sering dipakai di institusi tempat penelitian dijalankan, sehingga temuan yang didapat mungkin tidak bisa diterapkan pada merek kateter penghisap yang lain. Hal ini merupakan keterbatasan dari penelitian kami

\section{Kesimpulan}

Penelitian kami menunjukkan kedua metode pemrosesan ulang dua kali kateter penghisap memberikan hasil yang setara dalam hal sterilitas. Kateter penghisap yang dipakai ulang mengalami penurunan kekuatan, menjadi lebih lentur, dan tidak ulet. Adanya perubahan sifat permukaan, degradasi matriks, dan bukti kontaminasi pada kateter penghisap yang dipakai ulang, membuktikan perlu metode pemrosesan yang lebih baik.

\section{Ucapan terima kasih}

Ucapan terima kasih disampaikan kepada dr. Titik Nuryastuti, PhD atas kontribusi pada analisis mikrobiologi, bapak Rachmat untuk bantuan teknis uji mekanik, dan bapak Wikanda untuk bantuan teknis SEM dan analisis EDX.

\section{Daftar pustaka}

1. Rutala WA, Weber DJ, Healthcare Infection Control Practices Advisory Committee (HICPAC). Guideline for disinfection and sterilization in healthcare facilities. [Diakses pada 27 Oktober 2010]. Didapat dari: http:// www.cdc.gov/hicpac/pdflguidelines/Disinfection_Nov_2008.pdf

2. Pyrek KM. Reprocessing update: FDA continues its scrutiny of premarket submissions as healthcare professionals debate patient-safety issues. 2002. [Diakses pada 27 Oktober 2010]. Didapat dari: http://www.infectioncontroltoday.com/ articles/2002/02/reprocessing-update.aspx

3. Nanta P, Senarat W, Tribuddharat C, Danchaivijitr S. Cost-effectiveness and safety of reusable tracheal suction tubes. J Med Assoc Thai 2005;88:S86-8.

4. Alfa MJ, Nemes R. Inadequacy of manual cleaning for reprocessing single-use, triple lumen sphinctertomes: Simulated-use testing comparing manual with automated cleaning methods. Am J Infect Control 2003;31:193207.

5. Uroplast Suction catheter. Product Manual. [Diakses pada 27 Oktober 2010]. Didapat dari: http://www. goodman.hk/html/portex.html

6. Lee HB, Khang G, Lee JH. Polymeric Biomaterials. Dalam: Bronzino JD, penyunting. The Biomedical Engineering Handbook. Edisi kedua. Connecticut: CRC Press LLC, 2000.h.1-23.

7. Zimmerman BA. Medical devices: Reprocessed singleuse devices, termination of exemptions from premarket notification, requirement for submission of validation data. Federal Register 2005;70:56911-22.

8. Ayzman I, Dibs SR, Goldberger J, Passman R, Kadish A. In vitro performance characteristics of reused ablation catheters. J Intervent Card Electrophysiol 2002; 7:53-9.

9. Merrit K, Hitchins VM, Brown SA. Safety and cleaning of medical materials and devices. J Biomed Mater Res 2000;53:131-6.

10. Lipp MDW, Jaehnichen G, Golecki N, Fecht G, Reichl R Heeg P. Microbiological microstructure, and material science examinations of reprocessed combitubes ${ }^{\circledR}$ after multiple reuse. Anesth Analg 2000;91:693-7.

11. NHSScotland Property \& Environment Forum. Decontamination-cleaning, disinfection $\&$ sterilization. 2003.

12. Cleaning, disinfecting, and sterilizing plastics. [Diakses pada 27 Oktober 2010]. Didapat dari: http://www. gordonbrush.com

13. Merckx J, Kinget R. Ethylene chlorohydrin determination in ethylene oxide sterilized polyvinyl chloride tubing. J Clin Hosp Pharm 1986;11:357-63.

14. Rhim JW, Weller CL. Properties of formaldehyde adsorbed soy protein isolate films. Food Sci. Biotechnol 2000;9:228-33.

15. Balazs DJ, Triandafillu K, Chevolot Y, Aronsson BO, Harms H, Descouts P, dkk. Surface modification of PVC endotracheal tubes by oxygen glow discharge to reduce bacterial adhesion. Surf. Interface Anal 2003; 
Elisa dkk: Evaluasi mikrobiologi dan sifat mekanik kateter penghisap pakai ulang pada dua prosedur pemrosesan

35:301-9.

16. Gottenbos B, Busscher HJ, Van der Mei HC, Nieuwenhuis
P. Pathogenesis and prevention of biomaterial centered infections. J Mater Sci Mater Med 2002;13:717-22. 